Concept Paper

\title{
F(i)unding Your Way: A Managerial Compass for Social Organizations
}

\author{
Jessica Aschari-Lincoln ${ }^{1, *}$ and Barbara Scheck ${ }^{2}$ \\ 1 School of Management, University of St. Gallen, 9000 St. Gallen, Switzerland \\ 2 Entrepreneurship, Munich Business School, 80687 München, Germany; \\ barbara.scheck@munich-business-school.de \\ * Correspondence: jessica.aschari-lincoln@unisg.ch
}

Citation: Aschari-Lincoln, J.; Scheck, B. F(i)unding Your Way: A Managerial Compass for Social Organizations. Sustainability 2022, 14, 1396. https://doi.org/10.3390/ su14031396

Academic Editor: Donato Morea

Received: 19 December 2021

Accepted: 21 January 2022

Published: 26 January 2022

Publisher's Note: MDPI stays neutral with regard to jurisdictional claims in published maps and institutional affiliations.

Copyright: (C) 2022 by the authors. Licensee MDPI, Basel, Switzerland. This article is an open access article distributed under the terms and conditions of the Creative Commons Attribution (CC BY) license (https:// creativecommons.org/licenses/by/ $4.0 /)$.

\begin{abstract}
Social organizations are faced with an increasing diversification of funders, financial sources, and financing instruments and a growing complexity of funding relationships. They still prioritize social impact over financial returns, but funding considerations significantly influence the way these organizations operate. Existing models to understand the sector do not include this essential component, thus limiting insights and decision-making premises on how to reach as many beneficiaries as possible. Based on previous quantitative and qualitative research, this article conceptualizes the organizational, programmatic, impact, and financing strategies of social organizations and their interrelatedness in a new framework. This could be perceived as a managerial compass illustrating the multiple dependencies social organizations are confronted with. The compass aims at reducing complexity, serving as a tool for social organizations for more effective financial management. The article closes with a call for more analysis on how social organizations manage their multiple bottom line.
\end{abstract}

Keywords: social finance; nonprofit management; nonprofit funding; social enterprise

\section{Introduction}

Social organizations are defined as organizations that pursue a social mission for the benefit of individuals, groups, or society. While depending on financial resources to carry out their activities they do not seek to maximize financial profits but rather prioritize the social impact they are aiming for. They can have diverse organizational or legal structures, governance, and regulatory national contexts. Similarly, they dispose of different funding structures comprising all conceivable types of capital including grants, equity, and loans. Their common denominator and prevailing characteristic is the primary focus on achieving positive social change.

Previous academic research embraces the quasi-assumption that financial resources are per se available to social organizations in the global North, from a multitude of individual as well as institutional donors and public bodies. However, in practice, the relations between social organizations, their beneficiaries, and their financial sources are more complex [1-3] and go beyond the mere fundraising or resource dependency relationship: not all social organizations receive the funding they desire and not all financial sources find social organizations they want to fund. A pivotal research contribution to the understanding of the relationship is the benefits theory of nonprofit finance [4] that highlights the direct relation between the nature of U.S. nonprofit revenues (income/private versus giving/public) and social organizations' beneficiaries. Furthermore, the third sector is currently changing, combining traditional and more recent types of social organizations, financial sources, and ensuing relations [5]. The timing thus seems to be appropriate to reflect on this situation academically and provide guidance to practitioners.

This research views the interplay of social organizations and social finance providers as that of an emergent and ongoing alignment process occurring between demand and supply 
sides. The intersection between the two comprises various aspects such as a financial (e.g., interest return, equity percentage, loan repayment), programmatic (e.g., solution strategy, target group, service offered), or impact (e.g., evaluation of quantitative and/or qualitative impact) considerations. While being direct recipients of social finance, social organizations are in addition acting as intermediaries between social investors aiming for a certain effect and beneficiaries experiencing impact [1]. This contributes further to the complexity of the issue and goes beyond the theory of resource dependency.

The links among organizational, programmatic, impact, and financing strategies are not yet evident in current frameworks for social organizations. While there is separate analysis for the different components [6-9], financing strategies as a pre-requisite for all ensuing activities play a key role and need to be included in the management frameworks used for social organizations. This contribution aims to provide this conceptual overview of the different strategic elements building on previous empirical research [10-12] of one of the authors. These studies contributed to the understanding of the interplay between social organizations and social financial providers from different perspectives and in different contexts, identifying their interconnectedness.

Anheier's [13] call for more comprehensive management processes in the third sector is responded to in this article. It aims to shed light on the interrelation between social organization's organizational, programmatic, impact, and financing strategies in a dynamic setting, to summarize the findings, and to illustrate them graphically. We thus wish to simplify the complexity of management in the context of multiple bottom lines enabling social organizations to engage in more effective financial management. Furthermore, the integration and visualization of the underlying previous research findings can be perceived as a framework that provides both the researcher and practitioner with an overview of interrelations and processes to support understanding, reflection, and planning in social organizations. It aims at enabling the field to develop distinctive implementation strategies translating the strategic prioritization of social impact over financial profits into practice [14].

In the following, the paper provides an overview of the literature on the topic before elaborating on the methodology applied to derive the conceptual framework. Thereafter, the managerial compass is depicted and described before being extensively discussed. The article ends with a conclusion of the main insights of this contribution.

\section{Literature Review}

Heightened world interconnectedness as well as a new wave of burgeoning social enterprises $[15,16]$ have increased the pool of potential competitors for resources. Social enterprises are organizations employing a business model to generate social value [16]. Due to their revenue-generating organizational structure they can, in theory, address a larger group of social finance investors that also provide equity and debt capital in addition to grants. To address their funding needs, a new type of investors has emerged, often originating from the business sector, applying management practices to the third sector $[17,18]$. One example of funding approaches in this emerging field of social investment $[17,19]$ and new social investors are venture philanthropy funds (VPFs) [20]. They use concepts from venture capital finance and apply them to achieve philanthropic goals among more commercially oriented social organizations, such as social enterprises. VPFs fall under the category of social investors, yet they utilize both commercial (debt, equity, guarantees, hybrid financing, etc.) and philanthropic financial instruments (donations), and in Europe alone, their total investments are over 1 billion euros [21].

As a consequence, there is an increased demand from many sides for social organizations to manage their resources more effectively, in terms of resource acquisition, management, as well as reporting [22,23]. At the same time, social finance providerswhether foundations, governments, religious organizations, or social investors supplying grants, equity, debt, guarantees, hybrids, or other financial instruments-appear, in practice, to have specific pre-defined interests and priorities for their funding (for example, 
regarding certain issues, geographies, or target groups) [24]. Some foundations, such as the UBS Optimus Foundation, focus worldwide solely on beneficiaries that address issues related to children, and others, such as the Avina Foundation, engage in multiple fields, including education, culture, the environment, and social issues yet with a focus on Switzerland and Swiss-related initiatives. The same is true for social enterprises that are not looking for donations but more for equity investments or below-market debt suppliers; the supply has been growing steadily, with new market players, such as social angels and social investors, who also have specific priorities [25]. This adds to the complexity of resource acquisition from the social organization's perspective and limits the number of potential social organizations to be funded from the social finance provider's perspective. The sector is changing, with an increasing number of very diverse social organizations accessing different types of financing, highlighting the need for a new understanding of social finance, social impact, and the relations between the different actors involved [26-28].

Aside from the old and new financial sources and their priorities, the decrease in the decoupling between service beneficiaries and revenue sources to fund these services can be observed as a game-changing trend in the relationship between the involved parties [29]. The resource dependency theory no longer fully explains the relationship between social organization and funding source. Typical examples are philanthropic foundations and governmental welfare departments that receive financial resources from, for example, founder parents and use these to provide or enable services for certain beneficiaries. In other words, those that pay for the services are not those that receive the services. A reduction in this decoupling can be seen in different types of social organizations that are trying to align, to differing degrees, those that pay with those that receive. Some social finance providers are investors seeking a return on their investment, sometimes even with interest, which also qualifies them as recipients in the transaction [7]. In some cases, this alignment can be very direct because certain individuals and organizations pay fees to receive services. Sometimes this occurs more indirectly or through a negative effect, such as third parties that end up paying considerably more if the social service is not offered to the specific group of beneficiaries; for example, the government must pay the imprisonment costs for ex-prisoners who have a relapse. Mixing different strategies and types of financing instruments allows financing packages to be individualized according to the needs and possibilities of the social organizations and the social finance provider while at the same time rendering the relations between the actors more complex.

Another recent development relates to the use of performance metrics: the relation between social organizations and social finance providers is significantly affected by the latter's processes for mission-implementation, including evaluation and decision-making processes in both pre- and post-engagement phases. While being used to establish legitimacy prior to the investment, many social finance providers with the mission to increase the social impact now link payments over time to certain impact milestones that need to be achieved [19]. This behavior can either strongly affect or, in fact, determine the strategies and activities of the social organization.

At the beginning of their activities, during the proof-of-concept phase, social organizations usually focus primarily on achieving a social impact. There is a need to better understand the diverse kinds of social impact that social organizations produce, how these can be evaluated and reported at this point of time, not only due to the importance for social finance providers but also with regard to reflective learning processes within the organization $[8,30]$. In this phase, financing, as well as organizational growth issues, have a low priority, and organizations are generally in a "make-do" mode. Many social organizations remain in this phase, existing on short-term premises [31]. Some social organizations aim to grow and are faced with challenges regarding obtaining financing, spurring organizational growth, and increasing impact [32-37] during the scaling phase. Independent of which phase a social organization is in, it is necessary to have an understanding of the interplay between the organization and the societal need to be addressed, the mission and principles of the organization, the opportunities and possibilities that are presented, the strategies to 
be incorporated, the available resources, the activities to be conducted, the desired social impact, and the ability of the organization to tailor its financing.

Financing strategies are also especially relevant for a social organization's scaling phase. Most of the available research on scaling strategies can be largely categorized as relating to capacities, up and deep scaling [31,32]. In terms of definitions, capacities scaling focuses on developing organizational capacities, such as replication processes, exit strategies, governmental relations, technology development, and logistics processes; human resource capacities, such as employee management, effective board members, specialized skills and abilities, leadership skills, and staff training; and financial capacities, such as fundraising, negotiating, budgeting, and managing income/expenses [33-35]. Up-scaling is an approach focusing on the reach of the impact and thus on developing organizational structures and capacities to increase the number of beneficiaries [31,32]. Deep scaling is an approach focusing on the quality of the impact, thus improving and enriching the processes used to impact the beneficiaries [35]. Although the current prioritization of up-scaling and the related capacities simplifies the analysis in a hybrid context, it insufficiently mirrors the realities in practice and thus reduces the relevance of new insights. Deep social impact and deep scaling are complex, organic, and challenging to measure [32,33]. Practitioners have learned that growth in numbers alone does not translate linearly into qualitative growth [36,37]. Organizations are called upon to increase their social impact to address growing social problems; however, the concept of scaling can still be perceived as a black box. The literature on the scaling of social impact is growing and contributing insights to understanding this phenomenon but only in a fragmented manner and, generally, with certain heterogeneity in the research questions and approaches used [38]. The scaling phase of a social organization is a critical time when it is heavily dependent on financial sources. This highlights the need to also better understand how growth affects the interrelations between social organizations' organizational, programmatic, impact, and financing strategies.

Current frameworks or models that further the understanding of social organizations' functioning include the "foundation excellence-cockpit" (FE-C) model [6], the "inputoutput-outcome-impact" (IOOI) model [21], and the "organizing framework" [8]. Inspired by the St. Gallen management model [39] and its further development [9] for organizations, the FE-C [6] model uses a holistic approach and includes inputs, outputs, impact, and interactions. It, however, does not cover the issue of financing and its interrelation with programmatic management. The FE-C model was developed for foundations with funders or endowment funds that do not need to search for financing. The IOOI model is very helpful, even when using different definitions of impact, and is used by many social organization advisory boards. Again, however, issues related to financing are not included in the model and neither are other organizational issues and interactions. The "organizing framework" [8] is based on the work of Hambrick and Frederickson [40] and provides a more holistic and deeper understanding of value creation. This model shows the dynamic interactions among the mission and objectives, strategies, and impact measurement and includes the entrepreneurial adjustments that so often need to be made. However, this model is very general and does not specify the inputs, impacts, organizational issues, or financing strategies of social organizations. This overview highlights how links among organizational, programmatic, impact, and financing strategies are not yet evident in frameworks for social organizations.

Social organizations tend to lack an understanding of the interrelation between their programmatic and organizational characteristics and their access to social finance providers. Bagnoli and Megali [41] highlight the links among organizational processes, inputs, outcomes, and impacts that are necessary for understanding social organizations. Salamon and Sokolowski [2] point in their research to the influence of institutional, cultural, and societal factors on a social organizations' development in terms of funding, field, and focus. 


\section{Methodology}

The above-mentioned developments lead to organizational, programmatic, and impact characteristics affecting access to different financial providers, financing instruments, and pre- and post-financing processes. As a result, management and decision-making processes are even more challenging. Considering programmatic, organizational, financial, and impact management as a whole and including corresponding organic and dynamic complexity alleviates management complications and dichotomies [13]. Using such an integrative and aligned approach in a complex context that includes multiple bottom lines enables social organizations to realize more effective management and thus greater sustainability [8].

This contribution builds on previous research of one of the authors [10-12]. Each of these three papers relates and refers to many other published papers by other researchers, while at the same time having a similar fundamental theoretical framework based on both the resource dependency theory and the nonprofit theory of finance. The said research was an opportunity to use and build on these results, interpretations, and insights.

The research includes diverse contexts. The empirical perspective of social organizations, specifically, Swiss INGOs, and their worldwide involvement is considered. It also investigates the empirical perspective of social financing providers, specifically, worldwide Venture Philanthropy Foundations (VPFs) and foundations, and their worldwide engagement. In both cases, the focus is not on the home country of the INGOs, VPFs, or foundations but on the organizational, programmatic, impact, and financial strategies that are used. Both quantitative and qualitative research methods are used. The method of analysis is similar in the first two research papers and relies on a "snapshot" perspective by compiling quantitative databases and quantitative testing on the basis of current academic research and extensions thereof. Both use regression analysis. Due to the nature of the data, the first study uses a linear analysis and the second uses logistic regression. Robust models are developed to include the programmatic and organizational characteristics that affect the access to social finance providers and the choice between applying for a grant versus using a commercial financing instrument. The third research uses qualitative reconstruction [42] (which is an explorative research method. The impact investors' evaluation processes are well-documented, so pre-investment due diligence materials (around 20 pages per investee) and post-investment organizational capacity, programmatic, and financial reports are analyzed for each specific investment. This methodology avoids the biases and errors associated with self-reporting or retrospective reporting, as it uses neither a survey nor an experiment and is realized over time and within the natural environment [43].

The following figure (Figure 1) provides a visual overview of this research, with the asterisk $\left(^{*}\right)$ referring to the unit of analysis and the origin of the data (paper 1 [10]; paper 2 [11]; paper 3 [12]), and the arrows representing the quantitative (full arrow) and qualitative (dotted arrow) analyses undertaken.

The first paper revealed three key lessons. First, specific types of beneficiaries require specific revenue sources. Second, this study's extension of the benefits theory to additional programmatic and organizational characteristics noticeably increased the determination of the revenue source proportions. Third, there are clear differences in characteristics between different revenue sources. These findings revealed the need and opportunity for nonprofit organizations to adopt a comprehensive management approach by quantitatively demonstrating a relationship between INGOs and their revenue sources and developing predictive models of the financing by INGOs' different revenue sources based on programmatic and organizational characteristics.

The second paper focuses on venture philanthropy funds as new financial intermediaries and studies some characteristics of the investees. The empirical analysis is based on a unique dataset of 342 social investments from five continents over the last 17 years. Three main findings were notable. First, the investees' organizational and programmatic characteristics determine their access to financial resources. Second, a model including investees' organizational and programmatic characteristics strongly predicts grant versus 
commercial financing outcome. Third, the venture capital nature of venture philanthropy funds can be recognized from their financing instrument decision-making. Based on these findings, this research contributed to the emerging field of social investment.

\begin{tabular}{|c|c|c|c|c|}
\hline \multirow{2}{*}{ Social Organizations } & & & & \multirow{2}{*}{$\begin{array}{c}\text { Social Finance } \\
\text { Providers }\end{array}$} \\
\hline & $P 1, P 2$ & \multirow{2}{*}{ P1 } & $P 1$ & \\
\hline $\mathrm{P} 1 *$ & Programmatic, & & Available financing & P1 \\
\hline 119 Swiss INGOs & & & sources \& instruments & 8 Revenue sources \\
\hline & financial & & $P 2$ & \\
\hline $\mathrm{P} 2$ & characteristics & $\mathrm{P} 2$ & + Skills \& network & $\mathrm{P} 2 *$ \\
\hline 342 Social enterprises & & & & 30 International VPFs \\
\hline & $P 3$ & P3 & P3 & \\
\hline P3 & + Impact & 4 & + Scaling mission, & $\mathrm{P} 3 *$ \\
\hline 4 Social enterprises & characteristics & & strategies \& milestones & 1 International VPF \\
\hline
\end{tabular}

Figure 1. Overview of previous research contributions.

The third paper responded - on the basis of initial research on capacities, up and deep scaling strategies - to the need for integrated knowledge on financing processes within the context of social organizations' scaling phase. The findings from a qualitative inter-temporal analysis enabled the development of a model for scaling agreements and the pre- and postfinancing processes between social financial providers and recipients that shows on-going movement between provider and recipient of financial and non-financial resources and impact information as well as decision-making and reporting processes. This research made a fivefold contribution to the literature through its exploration of (1) financial providers' impact dependence for the sake of their own legitimacy, (2) the three scaling strategies of capacities, up and deep as interrelated and necessary dimensions of the sustainable growth, (3) further understanding of the growth of impact depth and its processes and interrelations, (4) the pivotal role of integrated perspectives and internal alignment between mission, strategy, reporting, and decision making processes, and (5) the effect of organizational, programmatic, financial, and impact characteristics on social organizations' access to financial providers, instruments, and pre- and per-financing processes.

In summary, the overall findings from these three papers were that organizational, programmatic, and impact characteristics determine access to financing via different providers, instruments, and pre- and post-financing processes. This contribution synthesizes the findings within a visualized framework, including both the financing dimension as well as the growth/scaling dimension.

The following table (Table 1) mentions some of the characteristics and factors relating to the organizational, resource, programmatic, impact, and financing strategies that were identified through quantitative and most especially through qualitative methods in the said research. The characteristics and factors are neither exhaustive nor prioritized. These are organized according to strategic field and can be relevant for several of them: for example, the life-cycle phase of a social organization affects an organization's general system strategies (governance, organizational culture, evaluation processes) as well as the type of financing available to it (seed vs. loan financing). The abovementioned frameworks or models that further the understanding of social organizations' functioning $[6,8,21]$ identify input (resources), output (activities), and outcome (impact) to be main determining fields. The said research demonstrates the need to add the field of financing as well as a general organizational field. As a result, the characteristics and factors are organized according to these five fields and their related strategies to be managed: organization (system strategies), input (resource strategies), output (activity strategies), outcome (impact strategies), and financing (financing strategies). 
Table 1. Interrelated strategies.

\begin{tabular}{|c|c|c|}
\hline $\begin{array}{l}\text { Strategic } \\
\text { Field }\end{array}$ & $\begin{array}{c}\text { Strategies } \\
\text { (Research P1, P2, P3) }\end{array}$ & $\begin{array}{c}\text { Relating } \\
\text { Characteristics }\end{array}$ \\
\hline Organization & $\begin{array}{c}\text { System Strategies } \\
\text { P1, P2, P3 }\end{array}$ & $\begin{array}{c}\text { Age, life-cycle phase } \\
\text { Distribution, replicable systems } \\
\text { Evaluation and reporting processes } \\
\text { Financial-providers' role (active, passive, etc.) } \\
\text { Legal, governance, board structures } \\
\text { Organizational needs, culture, goals } \\
\text { Nonprofit, for-profit, no-loss }\end{array}$ \\
\hline Inputs & $\begin{array}{c}\text { Resource Strategies } \\
\text { P1, P2, P3 }\end{array}$ & $\begin{array}{c}\text { Ecosystem } \\
\text { Finances } \\
\text { Materials, workspace } \\
\text { Network } \\
\text { People: employees, advisors, board, volunteers, etc. }\end{array}$ \\
\hline Outputs & $\begin{array}{c}\text { Programmatic } \\
\text { Strategies } \\
\text { P1, P2, P3 }\end{array}$ & $\begin{array}{c}\text { Activities per target group } \\
\text { Further development } \\
\text { General field of activities } \\
\text { Nature, prerequisites, activity interdependence } \\
\text { Regularity, sequence }\end{array}$ \\
\hline Outcome & $\begin{array}{c}\text { Impact Strategies } \\
\text { P1, P2, P3 }\end{array}$ & $\begin{array}{l}\text { Impact nature: deep/depth vs. up/breadth/width } \\
\text { Individual, community, society, ecosystem } \\
\text { Multipliers and critical factors } \\
\text { Phase: proof of concept, blueprint validation, scaling } \\
\text { Preventative vs. therapeutic } \\
\text { Sustainability } \\
\text { Target group(s) }\end{array}$ \\
\hline Financing & $\begin{array}{c}\text { Financing Strategies } \\
\text { P1, P2, P3 }\end{array}$ & $\begin{array}{c}\text { Cash Flow, overhead, budget, investment } \\
\text { Financial-providers' org. principles, impact dependence } \\
\text { Instruments: sales, equity, debt, donation } \\
\text { Sources: direct (target group), indirect } \\
\text { Spaces: crowd-funding, fundraising, grant applications, competitions }\end{array}$ \\
\hline
\end{tabular}

An organization encompasses a multitude of diverse system strategies ("organization") that are based both on choice as well as situation and have repercussions for the management of other strategies. For example, choices defining an organization's identity, such as ownership, profit, and goals, will affect the legal and governance structures, as well as the financing options. The life-cycle phase-i.e., proof-of-concept vs. growth or saturation - of an organization and its outputs influence the organizational distribution and replicable systems, the evaluation processes, as well as the financing opportunities. While these system strategies' characteristics and factors are few in number, they show how interrelated different aspects of an organization are and thus require ongoing re-alignment.

Resource strategies ("input") are both dependent from and determining of other strategies in the organization. People and the nature of their relation to the organizatione.g., employee vs. volunteer-influence the activities and impact to be achieved. At the same time, the financial situation of an organization will affect its attractiveness as an employer for people in different life phases. The list holds the obvious factors found in the previous research.

The dependence of programmatic strategies ("output") to both the systems and resource strategies is probably more obvious than its effect on impact strategies and vice versa. Not only the activities per say, but also their embeddedness, intensity, and multi-layered approach are determining for an organization's impact.

Impact strategies ("outcome"), let alone impact analysis and reporting of social organizations, are fields which both practitioners and academics are interested in learning more about. At the end of the day, a positive impact-whether it be quantitative, qualitative, 
or both-is the aim of every social organization. A number of characteristics and factors related to impact strategies were identified through the research, as playing a pivotal role such not only the target group and reach, but also the nature of the impact aimed for, its multipliers and critical factors as well as its potential and resilience for sustainability.

Financing strategies themselves are diverse, as the list shows, and affected by varying characteristics and factors from the opportunities available to the social organization to get known, to the financial instruments and their repercussions, e.g., debt vs. donations vs. equity vs. sales. Financing strategies ("financing") are also interlinked with the other strategies, both dependent from and determining of other strategies. As a result, financing strategies also need to be in an ongoing alignment process, as changes of factors such as life-cycle-phase, outcomes, or governance will call or even necessitate a change in financing strategies.

\section{Findings}

As previously mentioned, the links among organizational, programmatic, impact, and financing strategies is not yet evident in any current framework for social organizations. Financing strategies play a key role and need to be included in the management frameworks used for social organizations as they determine all other strategic fields. As defined by Ulrich and Probst [44], a system is a dynamic whole, with interdependent and interactive parts. This research studies such systems. To grasp the complexity of social organizations' decision-making processes, a certain reduction of reality's complexity is needed. A model or framework can be of value, even if it is simplified through abstractions, reductions, or generalizations [38]. Conant and Ashby [45] claim that a model is to act as a good regulator of a system. This research considers a model or framework as a design model used to illustrate the system and ensure its practical application.

When considering how the dynamic interrelations could be illustrated and enable practical application, a kind of map or compass was found to work best. The proposed framework (Figure 2) demonstrates certain dimensions and interrelations that are essential for management, inciting a comprehensive array of relevant questions, strategies, and lines of action. It provides both the researcher and practitioner with a comprehensive overview of interrelations and processes to support understanding, reflection, and planning. It does, however, not specify practical approaches to categorizing, measuring, evaluating, or reporting the five social impact, financials, resources, activities, and organizational fields. Its circular shape is chosen for its visual support of coherence and multiple interrelations.

The core of the framework consists of the three layers, identified societal need (in light grey), organizational mission (in grey), and internal logic (in grey), which is at the core of every social organization $[6,8]$. The societal need and organizational mission are consciously identified and more or less specified by the founders of social organizations. The internal logic, by contrast, can be conscious or not and can be communicated either internally or externally. Either way, it shapes the organization's strategy and its implementation [31,46]. A societal problem can and often must be addressed using different approaches. These can be implemented sequentially or simultaneously and depend on the problem; previous knowledge about its solution mechanisms, location, and size; and the structure of the target group. Furthermore, many social problems need to be addressed at different levels of society (micro, meso, and macro), in preventative as well as therapeutic ways, and by integrating a variety of stakeholders, including the final beneficiaries but not focusing solely on them. This specific problem-solving approach is often called the theory of change [47] and can apply to social organizations. For example, when identifying domestic violence as a societal problem to be addressed, organizations must work therapeutically with affected victims, preventatively with perpetrators, proactively by campaigning for better legislation on a macro level, etc. Hence, while the identified social need can be the same for various organizations, the respective circles of organizational mission and, especially, internal logic are likely to differ for each organization and are part of a dynamic process. The more conscious and specified these aspects are, the more focused the understanding, 
development, and reporting of the impact. Further, only in this manner is the organization, in itself coherent with its impact, externally legitimate [8]. Therefore, the societal need, organizational mission, and internal logic are placed at the core of this framework. These three layers both affect and are affected by the dynamic center of this framework and the outer layer. Insights into this fundamental role of societal need, mission, and internal logic come from the third research contribution [12].

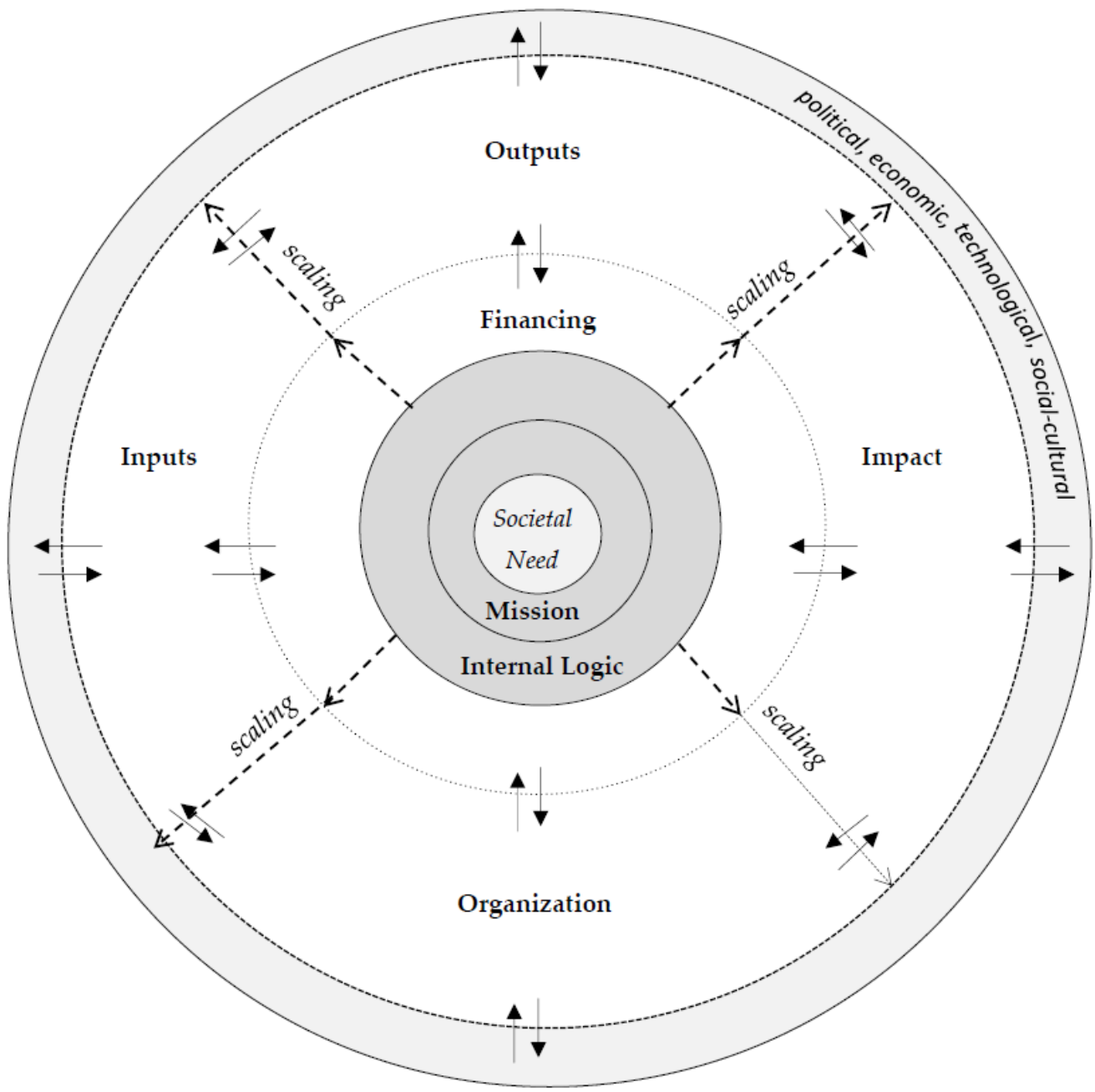

Figure 2. A managerial compass for social organizations.

The dynamic center of this framework (in white) has two dimensions depicting the level of operational strategies and its interrelations. The first dimension is that of financing, which can be seen as a lens. The financing sphere encompasses the organization's financing strategies and raises awareness of the different types of financial providers, instruments, and pre- and per-financing processes. As previously mentioned, research findings [12] showed both quantitatively and qualitatively, the interrelations between the financing, programmatic, organizational, and impact strategies: organizational, programmatic, and impact characteristics such as type/nature, region, field, focus, age/organizational size, governance form, stage in the life-cycle, return and growth potential, nature of the impact, scale readiness, reporting processes determine access to financing via different providers (e.g., generating income vs. receiving donated funds, individuals vs. foundations, etc.), instruments (e.g., commercial vs. philanthropic), and pre- and per-financing processes (e.g., due diligence, agreements, scaling strategies, milestones, reporting). Financing strategies play a key role in all development phases from seed to proof of concept to scaling. Changes in the four tranches of input, output, impact, and organization (second dimension of the dynamic center) can affect financing strategies either positively or negatively and vice 
versa. Further, due to the focus of this research on financing, financing strategies are not a fifth tranche but instead a sphere common to the four tranches of input, output, impact, and organization.

The second dimension encompasses the four tranches of input, output, impact, and organization. The "organization" tranche addresses system strategies: different structures and processes and systems are addressed, such as governance, legal frameworks, life-cycle stages, distribution and replicable processes, evaluation and reporting, organizational needs, and the financial provider's role. The "inputs" tranche is concerned with the organization's resource strategy, which includes issues around needed resources such as materials, a workspace, people, time, finances, the ecosystem, and the network. The "outputs" tranche encompasses the organization's strategies regarding its activities, which include the field(s) of the activities and the specific activities for each target group, including their regularity and sequence. The "impact" tranche encompasses the organization's change strategies and includes issues such as determining the direct vs. indirect target groups and the associated geography, using a preventative vs. therapeutic approach, working with different societal levels, developing a sustainability strategy, and understanding the organizational phases and the nature of impact and critical factors. Understanding these issues and their ramifications clarifies the impact the organization is aiming for, thereby facilitating impact measurement and a reflective learning process. Compared to the IOOI model [21], one aspect was not included in this framework, namely, outcomes. Outcomes are not included because of the overlap between outcomes and impact; impact can be defined as an outcome that goes beyond the direct target groups and may be very difficult to objectively measure. However, the term "impact" usually includes both meanings; i.e., the term "impact scaling" is commonly used rather than "outcome scaling".

A change in any of the above mentioned two dimensions-whether through a growth or decline in financing, inputs, outputs, impacts, or organization-will cause a ripple effect on the others as well as on the financing sphere and vice-versa. These circular interrelations are only partially represented in the framework (see arrows between the tranches), as these interrelations are not limited to the positions illustrated by the framework. The framework depicts how scaling strategies result in the expansion of each of these five fields (as shown by the expanding arrows and the dotted line). Indeed, the framework not only showcases the interrelations between organizational, resource, programmatic, impact, and financial strategies, but gets concrete with specific relevant characteristics and factors (see Table 1 above), thereby helping to increase understanding of management challenges and ensure a theoretical and practical orientation.

The outer ring (in light grey) represents the environment, with all its factors, such as political, economic, technological, and social-cultural-as in the St. Gallen management model $[9,39]$ - that affect the social organization's ecosystem and therefore both the dynamic center and the core of the framework. There is of course a very close link between the environment (outer ring) and the societal need (framework core). Retrospectively, the dynamic center (financing, organization, input, output, impact) also can affect these environmental factors to some degree; for example, some social organizations focus on changing the ecosystem.

The many arrows represent dynamic changes. The dotted arrows depict impulses of growth while the line arrows indicate potential influence. The arrows do not represent an automatic order of influence and change. Change and growth necessitate adjustments in the dynamic center (input, output, impact, organization, financing) if not also at the core of the framework (societal need, mission, internal logic) and can imply an increase in complexity.

\section{Discussion}

In reviewing the previously discussed functions of a model [9], this framework can help social organizations identify the relevant issues regarding action and decision-making; address the interrelated central questions, themes, and activities; understand management 
challenges; shape the development of potential courses of action; and make decisions on the basis of an integrated overview. This framework is both integrative in its inclusion of the various management facets of a social organization with multiple bottom lines and interactive in its comprehensive illustration of the interrelations. It should enable social organizations to better manage their organizations in an increasingly dynamic and heterogeneous environment by reducing complexity and focusing on their key characteristics. This is the first time such a holistic overview tailored to social organizations has been developed.

However, it constitutes a conceptual contribution that needs verification in practice and academic analysis in empirical set-ups. Furthermore, the model might be limited and non-exhaustive due to the underlying research. It would thus be interesting to test it in different organizational, legal, and cultural settings using multi-method approaches.

Regarding the academic discourse as well as the future development of research on the topic, there is a general need for theory-building research in the field of social finance. Studies on embedded reporting are still insufficient. How these differ from the mainstream fields of finance and accounting still needs to be further studied. For this purpose, better access to non-public qualitative and quantitative data is necessary. The research field of social finance is still relatively new, with few quantitative studies. Financial data on social organizations - especially in countries where social organizations do not complete tax returns-are difficult to obtain and are often weakened by their size and accuracy, as well as selection and survivorship bias. Publicly available data enable a "snapshot" view, without much depth and isolated from temporal and process contexts. While the qualitative longitudinal reconstruction of reporting and evaluation processes enabled a relatively less-biased analysis over 4 to 6 years, the quality of the written reports was not sustained over time. A higher turnover in human resources, especially when volunteers are engaged, makes in-depth research difficult.

The qualifications of "non-distributive" and "financial sources of a contributive nature" no longer do justice to this hybrid and dynamic market $[5,24]$. There is a wide array of diverse actors that, according to the context, are taking advantage of opportunities and using creativity to develop a diverse array of strategies and courses of action. Even the common understanding, according to the resource dependency theory, that a financial provider is in a position of power and independence can no longer be assumed [5,48]. Further research is needed on the interrelations between social organizations and these social finance providers: the added value in terms of a sustainable social impact and its growth for social enterprises financed by social investors, such as VPFs, still needs to be tested (see also [49]). Especially in developing countries, where financial sources are very scarce, more research is needed to better understand the extent to which social enterprises, through the influence of social investors, are not growing organically and in some cases are even negatively influenced [31]. In addition, given the emergence of new types of funders and funding instruments, it would be necessary to gain a better understanding if different types of funding have a distinguishing effect on the other characteristics mentioned in the managerial compass, and if so, how these effects materialize. s data disclosure is not similar to all types of social organizations and regulatory national context, research on information disclosure [50,51] and its interrelation with the five social impact, financials, resources, activities, and organizational fields identified and included in this paper's model could help the industry's development and researchers' understanding. More research that takes an integrative approach—such as Ebrahim and Rangan (2010) [26], with their contingencies grid delineating impact measurement practices according to the complexity of the social impact-would help to deepen the understanding of this field and provide a better basis for orientation. Further research is also needed on teamwork and leadership in social organizations with multiple bottom lines. Do team members with an understanding of both financial and social contexts in social finance organizations noticeably increase the sustainable social impact of financed social organizations? Which insights from the field of mediation can be translated into concepts to enhance the decision-making processes of hybrid organizations? How can competitive educational programs shape future 
multi-context minded collaborative servant leaders? What role do inductive reflective learning processes that are based on knowledge and driven from experience play in driving social impacts? In terms of contributions to practitioners, these findings can help ease their orientation to this hybrid and dynamic context. Being aware of and understanding the complexity of the relation between social organizations and social finance providers can help social organizations search more effectively for financial resources by helping them understand the links between organizational, resource, programmatic, impact, and financial management. These research findings help social organizations to-as mentioned by Crittenden [52]—focus and maximize their programmatic missions (e.g., increasing client use of services or marketing) and-as Anheier [13] notes-develop comprehensive and effective management approaches for the complex context of hybrid organizations. However, future research would need to test the framework and address issues such as weighting of different elements and their prioritization. Social organizations do not need to change their mission or strategies to access more resources. Social organizations need to more effectively acquire revenue sources by being aware of their own organizational, resource, programmatic, impact, and financial characteristics and by understanding that these shape and can both provide and eliminate financial opportunities. Social organizations should not only understand and communicate their own mission, internal logic, and impact [8], but should analyze their organizational, resource, programmatic, impact and financial strategies, delineating and adjusting their courses of action. Social organizations should report on their impact developments in relation to their mission and strategies. In addition, they should be aware of the interdependence between financial providers and recipients and of how this relationship affects the organizational mission and impact of both organizations. Regarding social finance providers, this research can help them understand and orient themselves to the more complex context of social organizations, with multiple bottom lines. The frustrations and challenges regarding the relations between a financial provider and recipient can be turned into stepping-stones.

\section{Conclusions}

The complexity in this field is increasing, which is both challenging and interesting for researchers and practitioners. Hybrid organizations, ventures, and collaborations across different sectors that originate from private, public, and social sectors are increasing. Understanding the dynamics of relations within a complex context and finding existing processes of alignment are instruments that can reduce the complexity. Dichotomies are being broken down or, at least as a first step, are being exposed [25,26]. The relevance of inductive bottom-up organic strategies, such as effectuation theory [27], has been acknowledged by academia. New styles of leadership, such as "multilingual leadership" [28], have been identified. Younger generations are showing weaker tendencies of dichotomizing social and financial issues [29]. Society and organizations are starting to consider the importance and relevance of having long-term rather than solely short-term perspectives in terms of risk level, return potential, social responsibility, and employee satisfaction.

Author Contributions: Conceptualization and submission preparation: J.A.-L. and B.S.; methodology: J.A.-L. All authors have read and agreed to the published version of the manuscript.

Funding: This research received no external funding.

Institutional Review Board Statement: Not applicable.

Informed Consent Statement: Not applicable.

Conflicts of Interest: The authors declare no conflict of interest. 


\section{References}

1. Evers, A. Mixed Welfare Systems and Hybrid Organizations: Changes in the Governance and Provision of Social Services. Int. J. Public Adm. 2005, 28, 737-748. [CrossRef]

2. Salamon, L.; Sokolowski, S. The social origins of civil society: Explaining variations in the size and structure of the global civil society sector. In Proceedings of the 9th International Conference of the International Society for Third Sector Research, Istanbul, Turkey, 7-10 July 2010.

3. Milligan, K.; Schöning, M. Taking a Realistic Approach to Impact Investing: Observations from the World Economic Forum's Global Agenda Council on Social Innovation. Innov. Technol. Gov. Glob. 2011, 6, 155-166. [CrossRef]

4. Young, D.R. Financing Nonprofits: Putting Theory into Practice; AltaMira Press: Lanham, MD, USA, 2007.

5. Nicholls, A.; Paton, R.; Emerson, J. Social Finance; Oxford University Press: Oxford, UK, 2015.

6. Lang, N.; Schnieper, N. Professionelles Management von Stiftungen; Helbing Lichtenhahn Verlag: Basel, Switzerland, 2008.

7. Hehenberger, L. European Venture Philanthropy Association. The European Venture Philanthropy Industry 2010/2011. 2012. Available online: https:/ / evpa.eu.com/knowledge-centre/research-and-tools (accessed on 25 January 2013).

8. Ormiston, J.; Seymour, R. Understanding Value Creation in Social Entrepreneurship: The Importance of Aligning Mission, Strategy and Impact Measurement. J. Soc. Entrep. 2011, 2, 125-150. [CrossRef]

9. Rüegg-Stürm, J. Das Neue St.Galler Management-Modell: Grundkategorien Einer Integrierten Managementlehre; Der HSG-Ansatz: Bern, Switzerland, 2003.

10. Aschari-Lincoln, J.; Jäger, U. Swiss International Nongovernmental Organizations (INGOs) and Their Financial Sources. In Proceedings of the 4th EMES International Research Conference on Social Enterprise, Liege, Belgium, 1-4 July 2013.

11. Spiess-Knafl, W.; Aschari-Lincoln, J. Understanding mechanisms in the social investment market: What are venture philanthropy funds financing and how? J. Sustain. Finance Invest. 2015, 5, 103-120. [CrossRef]

12. Aschari-Lincoln, J.; Jacobs, C.D. Enabling Effective Social Impact: Towards a Model for Impact Scaling Agreements. Sustainability 2018, 10, 4669. [CrossRef]

13. Anheier, H.K. Centre for Civil Society (London School of Economics and Political Science), Managing Non-Profit Organisations: Towards a New Approach; Centre for Civil Society, London School of Economics and Political Science: London, UK, 2000.

14. Bengo, I.; Borrello, A.; Chiodo, V. Preserving the Integrity of Social Impact Investing: Towards a Distinctive Implementation Strategy. Sustainability 2021, 13, 2852. [CrossRef]

15. Bansal, S.; Garg, I.; Sharma, G.D. Social Entrepreneurship as a Path for Social Change and Driver of Sustainable Development: A Systematic Review and Research Agenda. Sustainability 2019, 11, 1091. [CrossRef]

16. Cardella, G.; Hernández-Sánchez, B.; Monteiro, A.; Sánchez-García, J. Social Entrepreneurship Research: Intellectual Structures and Future Perspectives. Sustainability 2021, 13, 7532. [CrossRef]

17. Nicholls, A. The Institutionalization of Social Investment: The Interplay of Investment Logics and Investor Rationalities. J. Soc. Entrep. 2010, 1, 70-100. [CrossRef]

18. Spiess-Knafl, W. Financing of Social Enterprises-A Theoretical and Empirical Analysis; Technische Universität Münich: München, Germany, 2012.

19. Lall, S.A. From Legitimacy to Learning: How Impact Measurement Perceptions and Practices Evolve in Social Enterprise-Social Finance Organization Relationships. Volunt. Int. J. Volunt. Nonprofit Organ. 2019, 30, 562-577. [CrossRef]

20. Scarlata, M.; Alemany, L. Deal Structuring in Philanthropic Venture Capital Investments: Financing Instrument, Valuation and Covenants. J. Bus. Ethics 2010, 95, 121-145. [CrossRef]

21. Hehenberger, L.; Harling, A.-M.; Scholten, P. A Practical Guide to Measuring and Managing Impact. European Venture Philanthropy Association. 2013. Available online: https:/ / evpa.eu.com/knowledge-centre/research-and-tools. (accessed on 23 September 2013).

22. Nicholls, J.; Lawlor, E.; Neizert, E.; Goodspeed, T. A Guide to Social Return on Investment; The SROI Network: Liverpool, UK, 2012.

23. Luke, B.; Barraket, J.; Eversole, R. Measurement as legitimacy versus legitimacy of measures: Performance evaluation of social enterprises. Qual. Res. Account. Manag. 2013, 10, 234-358. [CrossRef]

24. Mitter, D. The Changing Face of Philanthropy. Indian Dev. Rev. 2017, 17, 18. Available online: https://idronline.org/the-changingface-of-philanthropy/ (accessed on 27 October 2021).

25. Chiapello, E.; Knoll, L. Social Finance and Impact Investing. Governing Welfare in the Era of Financialization. Hist. Soc. Res. 2020, $45,7-30$.

26. Ebrahim, A.; Rangan, K. The Limits of Nonprofit Impact: A Contingency Framework For Measuring Social Performance; Harvard Business School Working Papers; Harvard Business School: Boston, MA, USA, 2010; p. 10-099.

27. Leat, D. Grantmaking Foundations and Performance Measurement: Playing Pool? Public Policy Adm. 2006, 21, 25-37. [CrossRef]

28. Masaoka, J. The Effectiveness Trap. Stanf. Soc. Innov. Rev. 2003, 1, 82-83. [CrossRef]

29. Edwards, M. Just Another Emperor? The Myths and Realities of Philanthrocapitalism; Demos: London, UK, 2008.

30. Nicholls, A. Measuring Impact in Social Entrepreneurship: New Accountability to Stakeholders and Investors? University of Oxford: Oxford, UK, 2005.

31. André, K.; Pache, A.-C. From Caring Entrepreneur to Caring Enterprise: Addressing the Ethical Challenges of Scaling up Social Enterprises. J. Bus. Ethics 2016, 133, 659-675. [CrossRef] 
32. Desa, G.; Koch, J.L. Scaling Social Impact: Building Sustainable Social Ventures at the Base-of-the-Pyramid. J. Soc. Entrep. 2014, 5, 146-174. [CrossRef]

33. Dees, G.; Anderson, B.B. Scaling Social Impact. Stanf. Soc. Innov. Rev. 2004, 1, 24-32. [CrossRef]

34. Bloom, P.N.; Chatterji, A.K. Scaling Social Entrepreneurial Impact. Calif. Manag. Rev. 2009, 51, 114-133. [CrossRef]

35. Bloom, P.N.; Smith, B.R. Identifying the Drivers of Social Entrepreneurial Impact: Theoretical Development and an Exploratory Empirical Test of SCALERS. J. Soc. Entrep. 2010, 1, 126-145. [CrossRef]

36. van Fleet, J.W. Africa's Education Crisis: In School but Not Learning, The Brookings Institution. 2012. Available online: https://www.brookings.edu/blog/upfront/2012/09/17/africas-education-crisis-in-school-but-not-learning/ (accessed on 18 December 2021).

37. Dubb, S. How Nonprofit Programs Scale up: Findings from the Wallace Foundation. Nonprofit Quarterly. 2017. Available online: https://nonprofitquarterly.org/study-examines-challenges-expanding-reach-social-programs-larger-question/ (accessed on 18 December 2021).

38. Desantola, A.; Gulati, R. Scaling: Organizing and Growth in Entrepreneurial Ventures. Acad. Manag. Ann. 2017, 11, 640-668. [CrossRef]

39. Ulrich, H.; Krieg, W. St. Galler Management-Modell; Haupt: Bern, Switzerland, 1974.

40. Hambrick, D.C.; Fredrickson, J.W. Are you sure you have a strategy? Acad. Manag. Perspect. 2001, 15, 48-59. [CrossRef]

41. Bagnoli, L.; Megali, C. Measuring Performance in Social Enterprises. Nonprofit Volunt. Sect. Q. 2009, 40, 149-165. [CrossRef]

42. Petty, J.; Gruber, M. In pursuit of the real deal": A longitudinal study of VC decision making. J. Bus. Ventur. 2011, 26, 172-188. [CrossRef]

43. Fried, V.; Hisrich, R. Toward a Model of Venture Capital Investment Decision Making. Financ. Manag. 1994, 23, 28-37. [CrossRef]

44. Ulrich, H.; Probst, G. Anleitung zum ganzheitlichen Denken und Handeln; Ein Brevier für Führungskräfte; Haupt: Bern/Stuttgart, Switzerland, 1988.

45. Conant, R.C.; Ashby, W.R. Every good regulator of a system must be a model of that system. Int. J. Syst. Sci. 1970, 1, 89-97. [CrossRef]

46. Friedland, R.; Alford, R.R. Bringing Society Back In: Symbols, Practices, and Institutional Contradictions. In The New Institutionalism in Organizational Analysis; Powell, W.W., DiMaggio, P.J., Eds.; The University of Chicago Press: Chicago, IL, USA; London, UK, 1991; pp. 232-263.

47. Organizational Research Services. Theory of Change: A Practical Tool for Action, Results and Learning. Annie E. Casey Foundation. 2004. Available online: http://www.aecf.org/resources/theory-of-change/ (accessed on 18 December 2021).

48. Abercrombie, R. Power Corrupts, But Not the Way You Think. Alliance Magazine. 2016. Available online: http://www. alliancemagazine.org/blog/power-corrupts-but-not-in-the-way-you-think/ (accessed on 18 December 2021).

49. Jackson, E.T. Evaluating social impact bonds: Questions, challenges, innovations, and possibilities in measuring outcomes in impact investing. Community Dev. 2013, 44, 608-616. [CrossRef]

50. Carvalho, A.O.; Ferreira, M.R.; Lima, S. Web disclosure of institutional information in nonprofit organizations: An approach in Portuguese charities. Int. Rev. Public Nonprofit Mark. 2019, 17, 41-58. [CrossRef]

51. Carvalho, A.O.; Rodrigues, L.; Branco, M.C. Factors Influencing Voluntary Disclosure in the Annual Reports of Portuguese Foundations. Volunt. Int. J. Volunt. Nonprofit Organ. 2017, 28, 2278-2311. [CrossRef]

52. Crittenden, W.F. Spinning Straw into Gold: The Tenuous Strategy, Funding, and Financial Performance Linkage. Nonprofit Volunt. Sect. Q. 2000, 29, 164-182. [CrossRef] 